\title{
OCCUPATIONAL HEALTH IN A HOSPITAL SETTING
}

\author{
DOROTHY M. BLACKLAWS \\ OCCUPATIONAL HEALTH NURSE, VOLKSWAGEN S.A. (Pty)Ltd.
}

\section{OPSOMMING}

Aangesien gesondheidsdienste, veral hospitale, van die grootste werkgewers in die land is, behoort hulle werknemers dieselfde gehalte bedryfsgesondheidsorg te ontvang as die beste wat in die nywerheid aangebied word.

Daar is ' $n$ behoefte aan so 'n diens aangesien hospitaalwerknemers aan spesifieke gesondheidsrisiko's blootgestel is. Verder sal die diens dieselfde voordele aan werkgewers bied as in die nywerheid, naamlik gesonder en meer effektiewe werkers en ' $n$ afname in afwesigheid weens siekte en verlaagde personeelomset.

'n Bedryfsgesondheidsdiens in 'n hospitaal moet 'n onafhanklike eenheid wees waartoe alle werknemers toegang het. Streng vertroulikheid van rekords is essensieel.

Die diens wat so 'n eenheid bied, behels die volgende: indiensnemingsondersoeke, immunisering, gesondheidsvoorligting en raadgewing, daaglikse behandeling van bedryfs- en ander siektes en beserings, instandhouding van gesondheidsrekords van personeel, epidemiologiese studies van siektepatrone, monitor van omgewing vir geraas, ventilasie, humiditeit en veiligheid en beheer van kruisinfeksie waar nodig.

\section{INTRODUCTION}

$\mathbf{H}$ ealth services and especially hospitals, are amongst the employers with the largest number of employees in the country. Those employed in the service have the right to as high a standard of occupational health as found in industry at its best. Health services in hospitals should use techniques of preventive employees and reduces absenteeism due to sickness and other causes. It health requirements of the employees. Hospitals should serve as examples to the public regarding health education, preventive medicine and job safety.

Hospitals have a moral and legal obligation to:

- provide a safe and healthful working environment for employees;

protect employees from special risks and hazards associated with their occupations, such as contagious diseases;

- protect patients from risks associated with unhealthy employees.

Experience in other employee groups has shown that an occupational health service results in healthier, more effective employees and reduces absenteeism due to sickness and other causes. It also reduces labour turnover and Workmen's compensation and other insurance claims.

It is essential to establish a separate, independent facility and provide special personnel for a hospital occupational health service. The fact that hospitals are engaged in the care of the sick as their primary function does not alter the organisational plan necessary for an effective occupational health programme.

Health service employees, whether medical, para-medical, nursing, students or administrative, should be given the same facility by the occupational physician-nurse team wherever possible.

\section{THE NEED FOR AN OCCUPA- TIONAL HEALTH SERVICE}

A survey was undertaken by the author at two provincial hospitals with 956 and 985 employees respectively.

The hospital environment, health hazards and occupational health requirements were studied including:

- an examination of tasks undertaken by staff, the stresses and strains and the physical and mental requirements for such tasks;

- an assessment of health risks, dangerous substances used and methods of control;

- a study of environmental hygiene in all places of employment.

Requirements in relation to health examinations, health interviews, screening tests, education and the occupational health nurse's role in these were noted.

It was found that the occupational health programme, incorporating an adequate record system, would have to be planned to meet the needs of all em- ployees. The standards of prophylactic measures would have to be ascertained and policy determined. It was necessary to investigate accidents and their causes from previous hospital records to obtain a basis on which to form new safety and accident policies. Sickness absence amongst all employees was examined to identify causes and trends with a view to being able to cost sickness absence.

There was a definite need to establish meaningful methods of recording and compiling statistics pertaining to the health of hospital employees. Cross-infection within the hospital was examined to determine whether its prevention could be undertaken by the occupational health nurse or whether it required a separate appointment.

Selective placement of employees after adequate screening of their potential and health was found to be necessary. Counselling on various aspects affecting employees following employment was also needed.

Records and statistics pertaining to the health of employees were only obtainable from various offices and departments. An occupational health department would centralise these records and statistics, enabling meaningful measures to promote the health of workers and improved environmental and working conditions.

It was found that no records were kept on the effect of environmental working conditions on the health of the 
worker. No one was charged with the responsibility of initiating environmental investigations. Lighting and ventilation is regulated by the Provincial Planning and Works departments but is considered adequate and acceptable once the building is completed. Air, temperature, humidity or noise were not monitored. This is important as, for example, a noisy stair-well can annoy personnel in offices nearby. Food catering departments have to comply with provincial standards but did not have scheduled maintenance programmes for equipment. Standards could thus be lowered during the period of repair if equipment broke down.

Continued environmental surveys are needed in new buildings as well as old and this could be the responsibility of the occupational health nurse.

There were no safety officers, as those in industry, appointed in hospitals. The responsibility for safety rested with the Medical Superintendent and other senior personnel. Treatment after an accident was given initially in the casualty departments and the relevant workmen's compensation reports completed if it was a serious injury. Investigations of accidents were more for fact finding only and not as regulated, with a view to preventing a repeat accident, as they are in industry.

Fire precautions were regulated by the local municipal fire departments and checked six-monthly. There were no specific internal fire-fighting teams.

Wards appeared to be designed for patient comfort, but in many instances, what was suitable for the patient was an adverse environment for the staff. Staff rest rooms, toilets, shower facilities and their general layout were inadequate in most instances.

In industry each job is investigated and broken down to enable the personnel department to formulate job descriptions for all categories of workers. This enables the employer to ascertain the physical nature of a specific job. Because of the lack of job descriptions, hospital staff are employed in conditions to which some are not medically suited. Without an occupational health department and because there are so many different medical opinions in a hospital, it is difficult to avoid confusion and uncertainty concerning fitness for the job. A major difference between hospitals and industry is that there is no personnel department, resulting in a lack of policy concerning standards of employment as regards health matters.

\section{Medical or preplacement exam- inations}

Initial examinations for White employees in the hospitals were done by private practitioners who, because of the nature of their busy practice, do not really relate the examinations to the type of work the employee has applied for in the hospital.

Black employees, who were mostly domestic workers, were either examined at the Labour Department or at the hospital by the medical officer on duty at the time.

Most nursing staff were examined during their first month, either in the sick bay at the one hospital or in the casualty department at the other. Chest Xrays were taken, vision and hearing checked, and tests done for blood grouping, haemoglobin and venereal disease. Immunisations, for example BCG, were checked and updated.

There were no actual programmes for reassessment of the health of all categories of workers. As mentioned above, records were kept at different places for the various employees which made it difficult to compile statistics or do surveys.

\section{TABLE 1: ABSENTEEISM OF NURSING STAFF OVER A SIX MONTH PERIOD}

$\begin{array}{lrlr}\text { TOTAL NURSING STAFF }=300 & \\ \text { Trained staff } & 52 & \text { employees lost a total of } & 257 \text { days } \\ \text { Student midwives } & 10 & \text { employees lost a total of } & 19 \text { days } \\ \text { Student nurses } & 85 & \text { employees lost a total of } & 321 \text { days } \\ \text { Enrolled pupil } & & & \\ \text { nurses } & 55 & \text { employees lost a total of } & 166 \text { days } \\ \text { Nursing assistants } & 63 & \text { employees lost a total of } & 336 \text { days } \\ \text { Total } & 265 & & 1099\end{array}$

Monthly Average: 44 nursing staff lost 183 days

\section{Sickness absence}

Sickness absence was difficult to assess due to fragmentation of records. There were insufficient details to do epidemiological studies and no research studies had been done on occupational disease and injury of hospital employees.

Statistics obtained by the author for nursing staff absenteeism only are shown in Table 1.

The percentage of manpower lost due to sickness was $14,6 \%$ which is comparatively higher than figures in industry which average at $11 \%$ over a broad spectrum.

Severity rates of illness, such as the incidence of absenteeism often for short periods or absenteeism over long periods for severe illness could be determined from adequate centralised records. Repeated illnesses could provide valuable information for the prevention of sick absenteeism and promotion of the health of the workers.

\section{Health education}

Other than at the initial induction programme there was little or no specific health education given to the employees. It was felt that being hospital employees they should know all. This was particularly true for the actual nursing staff. Hoewever, following discussions with all categories of workers it was found that there was a need for health education, as in industry, in all fields for example in family planning, venereal disease, cross-infection, dangers of smoking and alcohol and drug abuse. Another important topic for education was accident prevention - particularly the prevention of back injuries, wounds and burns, chemical injury and physical strains and sprains, these being the most common types of injuries encountered by hospital employees. 
uation, all student groups, allied paramedical employees such as radiographers and physiotherapists, and those engaged in cleaning, maintenance and laundry.

It was apparent that the hospital personnel's view of staff care was orientated towards treatment and the concept of prevention had low priority. There were many medical opinions. There was an initial fear about confidentiality and a possible overlap with general practitioner services. The major positive response came from the nonmedical staff, such as laundry, X-ray, domestic and maintenance staff

The impartiality of counselling was questioned. It was obvious from the remarks of medical and nursing staff that they were not fully aware of the quality of the proposed occupational health service. A criticism was that hospitals were not factories and therefore do not have major hazards. From the aforegoing it should however be clear that hospitals do have their own hazards and environment which have to be understood.

Some interviewees were worried about where the department would be, who would give the service, how it would be done and the costs involved. The fact that the programme would be independent and confidential appealed to many, as well as the idea that there would be specific personal interest, follow-up and liason, and not competition with, private practitioners.

Various employees expressed the following needs:

- a specific place to report when sick or injured which is away from the actual hospital patients;

- confidentiality regarding all aspects of their attendance;

- independent personnel to examine, treat and counsel them when necessary;

- health promotion;

- safety training;

- personal interest and follow-up by the occupational health team;

- encouragement of recreation with the aim of physical fitness;

- a private, adequately staffed sick bay if warded for more than 12 hours (this would not be in the realm of an occupational health programme as it enters the curative field but it was important and is noted for this reason;

- a chiropody service;

- counselling on matters such as coping with death.

\section{THE REQUIREMENTS FOR AN OCCUPATIONAL HEALTH SER- VICE FOR HOSPITAL EM- PLOYEES}

The administrative requirements for an occupational health service for hospital employees are the following:

An executive committee consisting of members of the Hospital Management Committee and co-opted members.

An advisory committee - consisting of medical persons from outside the hospital such as from universities or the National Research Institute for Occupational Diseases.

Staff of the occupational health unit staff should include a registered nurse with a Diploma in Community Health Nursing and an occupational health certificate, an occupational health physician and a personal clerk/secretary.

Premises - Suitable, central premises should contain offices for the doctor and the sister, examination and treatment rooms, a rest room and toilet facilities as well as a reception area.

Documentation. Standardised cards must be designed for pre-employment and routine medical examinations, sickness absence, accidents and injuries, records of examinations and routine investigations. A daily record sheet must be available to indicate surgery attendances for occupational and non-occupational treatments. Environmental survey records are also required.

Rules of procedure - A policy to establish the relationship between the occupational health service and medical. nursing, and non-medical staff must be determined in which procedures for dealing with sickness and injuries as well as for communication between persons and departments in the hospital are laid down.

The following are important aspects regarding the relationship of the occupational health department with other departments in the hospital:

- the occupational health department should be completely independent to eliminate any suspicion of a lack of confidentiality;

- the department is responsible to the hospital management committee and matters affecting policy are discussed and approved by the medical superintendent, the matron and the administration manager;

- the occupational health medical officer and nurse must have access to all departments and should deal with the heads of these departments;

- all hospital employees must have access to the occupational health department.
Liaison with other bodies

General Practitioners. The occupational health service helps the hospital employees to use the services of the general practitioners correctly.

The general practitioners must be assured that the department is not encroaching on their field of work.

Committees within and outside the hospital. The occupational health nurse should be a member of the safety, crossinfection control, and welfare committees in the hospital and should attend local group meetings on safety and occupational health to obtain a broader perspective of her work. She should maintain contact with the local fire department, public health and labour departments.

\section{FUNCTIONS OF A HOSPITAL OCCUPATIONAL HEALTH SERVICE}

\section{Medical examinations}

Because of high staff-turnover it is not practical for the physician to examine all employees. Such a medical examination is time-consuming and costly. The most satisfactory method has been found to be an initial check on all employees using a medical questionnaire, together with an occupational health interview, examination and screening by the occupational health nurse. Screening includes Chest X-ray and seriological tests for haemoglobin and venereal disease. The nurse then refers only persons at special risk to the occupational health medical officer.

Persons at risk are as follows: student and pupil nurses; drivers; catering staff; disabled persons; X-ray workers; junior hospital medical staff and those required to have medical examinations by any specific regulations.

Medical and nursing staff's objections to medical examinations are soon overcome if there are specific directives.

The purpose of the medical examination/health interview is to establish:

- whether the employee is fit for job under consideration;

- whether there are any conditions which require treatment and therefore referral to his own general practitioner;

- whether the employee is medically at risk from the possible effect of work on his health:

- whether, for health reasons, the employee should be kept under surveillance by the occupational health department; 
- whether restrictions have to be put on his employment because of a possible effect of his health on work.

To establish the above it is necessary to have job descriptions to ascertain the exact nature of the specific job for which the employee is being considered.

Unlike industrial organisations, hospital staff work with colleagues who have knowledge of the significance of medical conditions. It is therefore of utmost importance that medical information be kept absolutely confidential. Heads of departments must accept the statement from the occupational health nurse that the employee is either fit or not fit to work, or requiring restrictions. This confidentiality will enhance the occupational health department's reputation.

\section{Immunisation procedures}

The transmission of infectious disease is a major hazard in a hospital and adequate immunisation procedures are required. The occupational health nurse should be responsible for this.

Protection may be provided against tuberculosis, tetanus, poliomyelitis, rubella and in some instances typhoid and influenza. Immunisation is necessary for all categories of employees.

\section{Health education}

Health education should be done by the occupational health nurse at the induction course for new staff. The education should stress safety and illness prevention. Furthermore. health education for all employees must be given on a regular basis. (Students receive lectures as part of their training.)

Health education by an occupational health nurse is an investment and is necessary if management is to avoid staff wastage from absence.

\section{Counselling}

Employees seek personal advice from many different people. As their confidence in the occupational health department increases counselling will become a major function of the occupational health nurse. With her specific training and experience she will be able to be of tremendous help in allaying stress and fears and reducing absence and staff turnover.

\section{Daily treatment}

Routine daily treatment of occupational and non-occupational conditions is undertaken by the occupational health department to reduce time lost from work.
Occupational conditions are those caused during and by the employee's work such as contact dermatitis of the hands due to detergent used by a cleaner, or lumbar strain due to lifting a heavy patient without assistance.

Non-occupational conditions can be home injuries or normal illnesses such as urinary tract infections or migraine headaches.

The author found that emergency conditions were treated in casualty departments and that minor conditions were treated in the staff sick bay in the one hospital studied and in the outpatient department in the other. All employees were able to attend their private practitioners if they so wished. Domestics were referred to their respective non-white hospitals where treatment was free. An occupational health programme would provide uniformity to treatment of employees on duty.

Occupational health services usually operate for eight hours. Only $8 \%$ of hospital staff, mainly nurses, work at night. Therefore any condition arising during night-duty can be treated at the hospital accident or medical departments. Reports should be forwarded to the occupational health department for follow-up.

\section{TABLE 2: EXAMPLES OF STUDIES WHICH COULD BE DONE FROM DAILY ATTENDANCE RECORDS}

\section{ATTENDANCES.}

Occupational causes.

Non-occupational causes.

Referrals to general practitioners.

Referrals from general practitioners.

Referrals to Consultants.

Immunisations.

\section{DAILY NON-OCCUPATIONAL ATTENDANCES.}

$\begin{array}{ll}\text { Headache } & \text { E.N.T. } \\ \text { Colds } & \text { Opthalmic } \\ \text { Digestive complaints } & \text { Dental } \\ \text { Dysmenorrhoea } & \text { Skin } \\ \text { Gynaecological } & \text { Back conditions } \\ \text { Home injuries } & \text { Feet } \\ \text { Chiropody } & \text { Medical conditions } \\ \text { Physiotherapy } & \text { Dressings } \\ \text { Psychiatric } & \text { Counselling }\end{array}$

\section{DAILY OCCUPATIONAL ATTENDANCES.}

Pre-employment examinations

Special examinations

Occupational interviews

Accidents/Injuries

Dressings

Dermatitis/allergies 


\section{Study of sickness patterns}

The occupational health nurse can furthermore do studies on sickness patterns using the above records. Information for sứch studies which was previously difficult to obtain will now be centralised in the occupational health department.

Sickness absence should be considered in terms of all absence. The data is required for two purposes:

- hospital management statistics;

- monitoring sickness absence of individuals, especially in respect of infections.

The first provides valuable information of the cost to the hospital of sickness absence and the second enables prompt control of cross-infection.

A satisfactory procedure should be determined for the collection of sickness absence data and the necessary records kept up to date.

\section{Environmental monitoring}

The responsibility for environmental monitoring should be defined in the occupational health service policy, thus ensuring the co-operation of departmental heads.

Regular surveys as well as spotchecks should be done. Lighting, temperature, humidity and noise are factors to be monitored. This requires special equipment which should be in the safe keeping of the occupational health nurse.

Standards of environmental hygiene should be maintained by the regular surveys. Ergonomic and stress factors should also be studied and adequate records kept of these.

\section{Cross-infection}

If cross-infection is controlled by a sister appointed for this purpose there should be a good liaison between her and the occupational health nurse. In the absence of such a person control of crossinfection could become a function of the occupational health nurse and she should be a member of the InfectionControl Committee.

\section{Safety}

Accident report forms should be kept in the occupational health department and on the basis of these, accidents should be analysed. Accidents can be analysed in terms of site of injury, staff classification, causes, and areas as shown in Table 3 .
The occupational health nurse should investigate and understand the causes of accidents and ensure that safety measures are initiated.

If there is a committee dealing with safety the occupational health nurse should be a member and submit regular reports. Standard procedures should be established for inspecting and monitoring the environment in terms of safety. Areas of particular concern include laundries, kitchens, workshops, X-ray departments, the central sterilisation

department, pharmaceutical departments and sewing rooms.

\section{Conclusion}

It is important to spend a considerable amount of time promoting an occupational health programme, consolidating and adding to existing procedures and obtaining the support of all departmental heads. It is essential to make employees aware that it is a promotive and preventive health service for all categories of workers.

\section{TABLE 3. ANALYSES TO BE DONE FROM ACCIDENT REPORT FORMS}

\section{TYPE AND SITE OF INJURY}

Lacerations, abrasions, wounds

Burns

Splinters

Back strain

Strains/Sprains and contusions

Infected wounds

Eye injuries

Ear injuries

Fracturers

Head injuries

Electric shock

Foot injuries

Hand injuries

\section{ACCIDENTS ACCORDING TO STAFF CLASSIFICATION}

Nurses

Doctors

Technical staff

Catering staff

Laundry staff

Maintenance staff

Administrative/Clerical staff

\section{ACCIDENTS ACCORDING TO CAUSES}

$\begin{array}{ll}\text { Falls } & \text { - floors, furniture, stairs } \\ \text { Wounds } & \text { - equipment, minor assaults by patients, laboratory } \\ & \text { processes } \\ \text { Strains } & \text { - lifting patients, equipment } \\ \text { Burns } & \text { - chemical, hot pipes, etc. } \\ \text { Malpractice } & \text { - cutting with razor blade instead of scissors, etc. }\end{array}$

ANALYSIS OF ACCIDENTS ACCORDING TO AREAS.
Wards

Corridors

Stairs

Theatres
Kitchens

Workshops

Grounds

$\mathrm{X}$-ray departments 